UDC 669.017: 621.73 .

\title{
ENHANCEMENT OF DURABILITY OF TRACTOR SUSPENSION AXLES
}

\author{
I. Doshchechkina, PhD., Assoc. Prof., I. Tatarkina, PhD., Assistant, \\ O. Storchak, PhD., Assoc. Prof., \\ Kharkiv National Automobile and Highway University
}

\begin{abstract}
The 'soft' nitriding of the suspension axle surface of the T150K tractor at the depth of $0.08 \mathrm{~mm}$ enables us to enhance its constructive strength, to increase its service life by $25 \%$ and have a considerable economic effect.
\end{abstract}

Key words: steel, surface, nitriding, layer thickness, core, tension test, deformation, destruction, strength, flexibility, tractor suspension axle, service life increase.

\section{ПОВЫШЕНИЕ ДОЛГОВЕЧНОСТИ ОСЕЙ СИСТЕМЫ ПОДВЕСКИ TPАКТОРА}

\author{
И.В. Дощечкина, доц., к.т.н., И.С. Татаркина, ассист., к.т.н., \\ О.Г. Сторчак, доц., к.филол.н., \\ Харьковский национальный автомобильно-дорожный университет
}

\begin{abstract}
Аннотация. Показано, что «мягкое» азотирование на глубину 0,08 ми поверхности осей системы подвески трактора Т150к позволило повысить их конструктивную прочность, увеличить ресурс на $25 \%$ и получить значительный экономический эффект.
\end{abstract}

Ключевые слова: сталь, поверхность, азотирование, толщина слоя, сердиевина, испытание на растяжение, деформация, разрушение, прочность, пластичность, оси подвески трактора, эксплуатачионный ресурс.

\section{ПІДВИЩЕННЯ ДОВГОВІЧНОСТІ ОСЕЙ СИСТЕМИ ПІДВІСКИ ТРАКТОРА}

\author{
І.В. Дощечкіна, доц., к.т.н., І.С. Татаркіна, асист., к.т.н., \\ О.Г. Сторчак, доц., к.филол.н., \\ Харківський національний автомобільно-дорожній університет
}

Анотація. Показано, що «м'яке» азотування на глибину 0,8 мм поверхні осей системи підвіски трактора Т150к дозволило збільшити їх конструктивну міџність, збільшити ресурс на 25 \% $і$ отримати значний економічний ефект.

Ключові слова: сталь, поверхня, азотування, товщина шару, сериевина, випробування на розтягування, деформація, руйнування, міџність, пластичність, осі підвіски трактора, експлуатаиійний ресурс.

\section{Introduction}

In most cases, the service life of generally reliable and durable wheeled and caterpillar vehicles is limited by premature failure of separate parts and units. Frequent stops disrupt the smooth operation, increase the amount of metal when replacing spare parts. It leads to significant losses to an economic agent.
According to the Ukrainian Association «Reliability of Machines and Facilities», the loss of metal for the spare parts of the tractor chassis is more than $90 \%$ during operation. Tractor overhaul life is $40-50 \%$ in comparison with repair one. $60-80 \%$ of costs are spent to remove failures [1]. 
Most of the tractors, which are in operation at present, were manufactured more than 25 years ago and have been considerably worn out. Their replacement is not foreseen in the near future as there are no funds to pay for orders and the production generally goes down. So the main burden is on repair plants. Under such conditions, the enhancement of service properties and the service life of the repair kits of the resourcedetermining units of machines is really topical.

\section{Analysis of Publications}

The most important factor that stipulates the durability and the service life of various constructive parts of machines is a surface state, which determines the operation characteristics of the material of the units in terms of friction and wear and tear, the effect of cyclic loadings and the aggressive environment.

The paper [2] proves that the surface state significantly influences the curve «stressdeformation», the brittle and fatigue failures of a unit. Researcher V. Panin [3] also underlines that the surface layer plays the main role in terms of the failure nature, place and time.

The review by O. Stepanov [4] emphasizes that the treatment of surface has an impact on the diagram 'stress-deformation'. The mechanical properties of materials are stipulated by both the composition and the thin structure of surface that can cause the anisotropy of elasticity and strength, which impedes a failure in some directions and creates conditions for the enhancement of strength.

The reinforced surface layer can be made by means of chemical-thermal treatment or surface deformation. Paper [5] is devoted to the impact of various types of chemical-thermal treatment upon the mechanical properties of units. It can be concluded that the surface cemented layer completely embrittles the material.

Nitriding influences the mechanical properties of steel in different ways. The nitriding of lowcarbon steel increases strength $\left(\sigma_{\mathrm{B}}\right.$ by $13 \%, \sigma_{02}$ by $25-35 \%$ ), but flexibility goes down up to zero and absolutely subtle destruction takes place. Medium-carbon steel changes insignificantly $\left(\sigma_{\mathrm{B}}\right.$ decreases by $7 \%, \sigma_{02}$ increases approximately by $1.5 \%$.
The authors come to the conclusion that neither nitriding nor cementing can be useful to increase the constructive strength of units. There are some works that show no impact of a surface layer state upon either the behaviour under loading or the properties of the unit in general [6].

It is known that the reason for the most premature failures is wear and tear. So the search of the ways to create wear-resistant surface layers without deterioration of the unit core properties is topical at present as the volume of the repair work of worn out agricultural and roadconstruction machines has considerably increased.

\section{Research Purpose}

The tractor suspension is prone to a premature failure. The suspension axles are operated in heavy conditions of intensive abrasive wear and tear. They can also be corroded under the considerable humidity of ground. In addition, the units operate under tension and cyclic loadings. Therefore, their surface must be wearresistant and rust-proof, whereas the core must be rather flexible and tough but quite strong.

The purpose of this research is to discover the correlation between the mechanical characteristics and the failure nature of the axles under tension depending on the thickness of the surface layer reinforced by chemical-thermal treatment.

\section{Material and Methodology of Research}

The axles of the repair kit of the suspension are manufactured using steel $40 \mathrm{X}$ and 38XGT (38ХГТ). Their thermal treatment is hardening with further high tempering.

We investigate steel $40 \mathrm{X}$ having the chemical composition as mentioned in table 1 .

Table 1 Chemical composition of steel under $\underline{\text { research }}$

\begin{tabular}{|c|c|c|c|c|c|c|}
\hline $\begin{array}{c}\mathrm{C}, \\
\%\end{array}$ & $\begin{array}{c}\mathrm{Si} \\
\%\end{array}$ & $\begin{array}{c}\mathrm{Mn}, \\
\%\end{array}$ & $\begin{array}{c}\mathrm{Cr}, \\
\%\end{array}$ & $\begin{array}{c}\mathrm{S}, \mathrm{P} \\
\%\end{array}$ & $\begin{array}{c}\mathrm{Ni}, \\
\%\end{array}$ & $\begin{array}{c}\mathrm{Cu}, \\
\%\end{array}$ \\
\hline $\begin{array}{c}0.42- \\
0.44\end{array}$ & $\begin{array}{c}0.2- \\
0.3\end{array}$ & $\begin{array}{c}0.5- \\
0.6\end{array}$ & 1.1 & 0.03 & 0.25 & 0.30 \\
\hline
\end{tabular}

Standard cylindrical breakage samples, which are made of steel 40X (10 mm), after enhancing 
- hardening in the oil under temperature $860{ }^{\circ} \mathrm{C}$, tempering $650{ }^{\circ} \mathrm{C}$, the soaking for 1.5 hours (hardening and high tempering), are nitrided.

Nitriding is made using three modes to harden the layers of various thickness $h-0.08 ; 0.25$; $0.35 \mathrm{~mm}$ : 1 mode: nitriding under $\mathrm{t}=640^{\circ} \mathrm{C}$, $\tau=1.5 \mathrm{hrs} ; 2$ mode: nitriding in a flow of ammonia under $\mathrm{t}=520^{\circ} \mathrm{C}, \tau=10 \mathrm{hrs}$, increase of temperature by $54{ }^{\circ} \mathrm{C}, \tau=20 \mathrm{hrs}$, then soaking for $3 \mathrm{hrs}$ without ammonia and further colling to $150^{\circ} \mathrm{C}$ in a flow of ammonia; 3 mode: re-nitriding of the samples, which have been treated in mode 2.

Strength and flexibility are investigated, using the standard methodology to test the samples under tension. The hardness of a thin nitrided layer is measured by Vickers hardness tester. The hardness of the tough core is measured by Brinell hardness tester using the ball of $\varnothing 5 \mathrm{~mm}$.

\section{Research Results}

The tension diagram and the protocol of sample tests are in figure 1 and table 2.

The data indicate that deep nitriding $(0.25$ and $0.35 \mathrm{~mm}$ ) brings about the decrease of strength, the loss of flexibility and embrittlement (curves $3,4)$. Low nitriding $(0.08 \mathrm{~mm})$ slightly increases strength under very high flexibility (curve 2) that corresponds to the level of the sample that has not been thermally treated (curve 1). So the nitriding as deep as $\delta \leq 0.08 \mathrm{~mm}$ does not decrease the constructive strength of the unit. It is proven by quantitative values of strength and flexibility, which are determined by the methods of mathematical statistics (table 2).

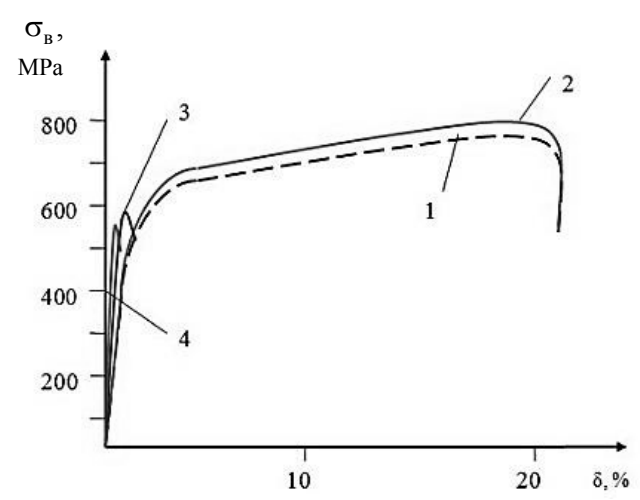

Fig. 1. Diagram of tension of samples of steel 40X: 1 - hardening + high tempering; 2 nitrided layer $0.08 \mathrm{~mm} ; 3$ - nitrided layer $0.25 \mathrm{~mm} ; 4$ - nitrided layer $0.35 \mathrm{~mm}$ $\underline{\text { Table } 2 \text { Mechanical characteristics of samples after }}$ various types of treatment

\begin{tabular}{|c|c|c|c|c|}
\hline $\begin{array}{c}\text { Nitrided layer } \\
\text { thickness, mm }\end{array}$ & $\begin{array}{c}\sigma_{\mathrm{B}}, \\
\mathrm{MPa}\end{array}$ & $\begin{array}{c}\sigma_{02}, \\
\mathrm{MPa}\end{array}$ & $\begin{array}{c}\delta, \\
\%\end{array}$ & $\begin{array}{c}\Psi, \\
\%\end{array}$ \\
\hline $\begin{array}{c}\text { Hardening and high } \\
\text { tempering }\end{array}$ & 715 & 430 & 20 & 52 \\
\hline 0.08 & 790 & 455 & 20 & 48 \\
\hline 0.25 & 580 & 530 & - & - \\
\hline 0.35 & 545 & - & - & - \\
\hline Removed layer & 715 & 420 & 21 & 51 \\
\hline
\end{tabular}

Having removed the nitrided layer, the mechanical properties are consistent with the values after enhancement (hardening and high tempering).

The correlation between temporary resistance and nitrided layer thickness for the samples having diameter 5 and $10 \mathrm{~mm}$ is in figure 2 .

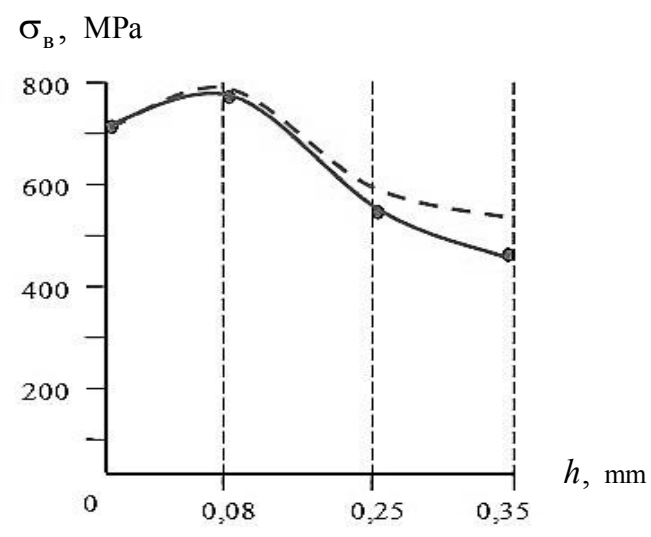

$\delta_{\mathrm{B}}=f(h)$ for samples $\varnothing 5 \mathrm{~mm}$

$\delta_{\mathrm{B}}=f(h)$ for samples $\varnothing 10 \mathrm{~mm}$

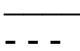

Fig. 2. Correlation between temporary resistance and nitrided layer thickness $h$

Figure 2 indicates that the temporary resistance exponentially depends on the reinforced layer thickness $h$. If $h \leq 0.08 \mathrm{~mm}$, the temporary resistance increases, but its further increase leads to the decrease of $\sigma_{b}$.

The samples that have been destroyed during the tension tests are in figure 3.

The figure shows that the increase of the nitrided layer thickness leads to the shift of the breakage place to the top of the samples towards the basic concentrator of tension. 


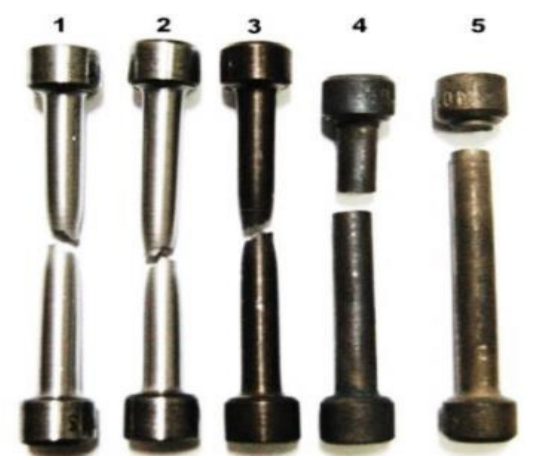

Fig. 3. Exterior view after tension tests: $1-$ hardening + high tempering; 2 - mechanically removed nitrided layer; 3 - nitrided layer $0.08 \mathrm{~mm}$; 4 - nitrided layer $0.25 \mathrm{~mm}$; 5 - nitrided layer $0.35 \mathrm{~mm}$

The samples, which have been nitrided as deep as $\delta \geq 0.08 \mathrm{~mm}$ (4 and 5), are broken as absolutely brittle, there are no cracks along the working length when tested.

The samples, which have the reinforced layer of $0.08 \mathrm{~mm}$ (3), are broken in the middle of the working area and the neck is made by analogy with the samples after enhancement (1) and with a removed nitrided layer (2).

Having been nitrided as deep as $0.08 \mathrm{~mm}$, the tension of the sample leads to the increase of the sample strength, whereas the value of flexibility does not decrease.

\section{Conclusion}

It is experimentally proven that the modified layer thickness has an impact upon the behaviour of the units under tension: the thicker the reinforced layer is, the more brittle material is. Deep reinforced layers cause unwanted brittle destruction.

To increase the surface hardness and strength and simultaneously increase the strength of the core as well as save the flexibility characteristics of the core, the nitriding must be equal or less than $0.08 \mathrm{~mm}$ deep.

Nitriding is known to increase corrosion resistance that is especially vital for the parts of the suspension units, which operate in severe weather conditions under considerable humidity.

The soft nitriding up to $0.08 \mathrm{~mm}$ is used at the state enterprise «Kharkiv Mechanical Plant» for the repair kit of the axles of the tractor T150K suspension, increasing their service life by $25 \%$.

\section{Литература}

1. Кухтов В.Г. Долговечность деталей шасси колёсных тракторов / В.Г. Кухтов. - Х.: ХНАДУ, 2004. -292 с.

2. Алехин В.П. Физика прочности и пластичности поверхностных слоев материалов / В.П. Алехин. - М.: Наука, 1983. $280 \mathrm{c}$.

3. Panin V.E. Multilevel wave model of a deformed solid in physical mesomechanics / Panin V.E., Grinyaev Yu.V., Panin A.V., Panin S.V. // Proceedings of the Sixth International Conference for Mesomechanics «Multiscaling in Applied Science and Emerging Technlogy. Fundamentals and Applications in Mesomechanics». - 2004. - P. 335-342.

4. Степанов А.В. Явления искусственного сдвигообразования / А.В. Степанов // Журнал технической физики. - 1948. т. 18. - С. 741-778.

5. Пономаренко I.В. Підвищення конструктивної міцності сталевих виробів шляхом поверхневого наноструктурування іонним бомбардуванням: автореферат дис. на здобуття наук. ступеня кандидата технічних наук : спец. 05.02.01 «Матеріалознавство» / I.В. Пономаренко. Харків, 2011. - $21 \mathrm{c}$.

6. Gilman J. Surface Effects in the Slip and Twinning of Metal Monocrystals / J. Gilman // Transactions of the American Institute of Mining and Metallurgical Engineers. - 1952. - Vol. 194. - P. 875-883.

\section{References}

1. Kuhtov V.G. Dolgovechnost' detaley shassi kolesnykh traktorov [Durability of parts chassis wheel tractors], Kharkov, HNADU Publ., 2004. 292 p.

2. Alekhine V.P Fizika prochnosti $i$ plastichnosti poverkhnostnykh sloev materialov [Physics of strength and plasticity of the surface layers of materials], Moscow, Science Publ., 1983. 280 p.

3. Panin V.E., Grinyaev Yu.V., Panin A.V., Panin S.V. Multilevel wave model of a deformed solid in physical mesomechanics. Proceedings of the Sixth International Conference for Mesomechanics «Multiscaling in Applied Science and Emerging Technlogy. Fundamentals and Applications in Mesomechanics». 2004. pp. 335-342. 
4. Stepanov A.V. Yavleniya iskusstvennogo sdvigoobrazovaniya [The henomenons of artificial sdvigoobrazovanija], Journal of Technical Physics. 1948. vol. 18. pp. 741-778.

5. Ponomarenco I.V. Pidvishchennya konstruktivnoï mitsnosti stalevikh virobiv shlyakhom poverkhnevogo nanostrukturuvannya ionnim bombarduvannyam [Increase of items structural strength by surface nanostructuring with the help of ion bombardment], abstract of a thesis... candi- date of technical sciences: special. 05.02.01 «Material Science»/ Kharkov, 2011.21 p.

6. Gilman J. Surface Effects in the Slip and Twinning of Metal Monocrystals. Transactions of the American Institute of Mining and Metallurgical Engineers. 1952. Vol. 194. - pp. 875-883.

Рецензент: М.А. Подригало, профессор, д.т.н., ХНАДУ . 